\title{
Evaluation of DNA Amplification Methods for Improved Detection of "Candidatus Liberibacter Species" Associated with Citrus Huanglongbing
}

\author{
Wenbin Li, National Plant Germplasm and Biotechnology Laboratory, USDA-APHIS-PPQ-CPHST, Beltsville, MD \\ 20705; John S. Hartung, Fruit Laboratory, USDA-ARS, Beltsville, MD 20705; and Laurene Levy, National Plant \\ Germplasm and Biotechnology Laboratory, USDA-APHIS-PPQ-CPHST, Beltsville, MD 20705
}

\begin{abstract}
Li, W., Hartung, J. S., and Levy, L. 2007. Evaluation of DNA amplification methods for improved detection of "Candidatus Liberibacter species" associated with citrus huanglongbing. Plant Dis. 91:51-58.

Citrus huanglongbing (HLB), also known as citrus greening or citrus yellow shoot, is considered the most serious disease of citrus worldwide. The disease has Asian, African, and American forms caused by "Candidatus Liberibacter asiaticus", "Ca. L. africanus", and "Ca. L. americanus", respectively, which can be spread efficiently by the psyllid vectors Diaphorina citri and Trioza erytreae and through contaminated plant materials. Infected citrus groves are usually destroyed or become unproductive in 5 to 8 years. The presumed low concentration and uneven distribution of the pathogens in citrus plants and vector insects make the phloem-limited bacterium difficult to detect consistently. In this study, we compared and validated four conventional polymerase chain reaction (PCR)-based protocols, one loop-mediated isothermal amplification (LAMP) protocol, and three TaqMan real-time PCR protocols. The detection sensitivity of the validated conventional PCR assays reported are improved compared with the original protocols. All of the validated conventional and the newly developed real-time methods were reliable for confirmatory tests for the presence of "Ca. Liberibacter spp." in symptomatic samples. There were no differences in assay specificity among the standard format PCR-based methods evaluated. The TaqMan real-time PCR was 10- to 100-fold more sensitive than conventional PCR and LAMP, showing the potential to become a valuable tool for early detection and identification of "Ca. Liberibacter spp." prior to the appearance of disease symptoms. The methods validated in this study will be very useful for regulatory response, effective management of infected trees, and development of a " $\mathrm{Ca}$. Liberibacter spp."-free nursery system.
\end{abstract}

Additional keywords: citrus greening, HLB, molecular detection, phloem-limited bacterium

Citrus huanglongbing (HLB), also known as citrus greening (3), is considered the most serious disease of citrus worldwide (8). The disease has long been present in Asia, Africa, the Indian subcontinent, the Mascarene Islands, and the Arabian Peninsula (2). It has only recently been found in South and North America $(16,26)$. The pathogen is a gram-negative bacterium belonging to the alpha subdivision of the proteobacteria (12). Because the bacterium has never been cultured in vitro, the name of the organism has provisional ("Candidatus") status in nomenclature. The disease has Asian, African, and American forms caused by "Candidatus Liberibacter asiaticus" (Las), "Ca. L. africanus" (Laf), and " $\mathrm{Ca}$. L. americanus" (Lam), respectively $(12,28)$. Besides transmission through propagation of plant materials $(1,18,21)$, the disease can be

Corresponding author: Wenbin Li

E-mail: Wenbin.Li@aphis.usda.gov

Accepted for publication 17 August 2006.

DOI: 10.1094/PD-91-0051

(C) 2007 The American Phytopathological Society vectored efficiently by the psyllids Trioza erytreae and Diaphorina citri $(19,24)$. Infected citrus groves are usually destroyed or become unproductive in 5 to 8 years following infection (6). D. citri has become established in Florida since its introduction in 1998 (7) and in Texas in 2001 (4). A Las strain was first detected and confirmed in various counties of Florida in 2005 (16). The disease is now of great concern to the entire U.S. citrus industry.

The nonspecific nature of HLB symptoms makes it initially difficult to distinguish this disease from nutrient deficiencies or other plant diseases. The presumed low concentration and uneven distribution of the pathogens in host plants and vector insects make the pathogens difficult to detect consistently. Many detection methods have been described, including the use of biological grafted plant assays (23), the presence of specific fluorescent substances in infected plants (25), light or electron microscopy $(14,30)$, or enzyme-linked immunosorbent assay (ELISA) (5). Although molecular approaches have been developed for detection and/or differentiation of "Ca. Liberibacter spp." based on DNA amplification by conventional poly- merase chain reaction (PCR) $(10,11,13$, 27,29), real-time PCR $(16,17)$, and loopmediated isothermal amplification (LAMP) (22), consistent detection of the pathogens in infected plants or vector insects still remains problematic (16). Suspect plants are usually identified in the field by foliar blotchy mottle symptoms and/or lopsided fruit. The diagnosis is then confirmed by conventional and real-time PCR assays. Although PCR assays are accepted as confirmatory tests for HLB surveys in locations such as the state of São Paulo, Brazil, and Florida, USA, the potential of these assays to improve detection of " $\mathrm{Ca}$. Liberibacter spp." in host plants or vector insects has never been critically evaluated.

The objective of this study was to compare several conventional PCR-based assays with LAMP and with our newly developed TaqMan real-time PCR system (16) for accurate, sensitive, and specific detection of HLB pathogens in the tissues of greenhouse- and field-grown plants. This is important because the various DNA amplification-based assays have been developed separately and validated with limited numbers of strains of the pathogen. A systematic comparison of the existing assays, on a uniform and extensive set of plant samples, will provide needed data to make an informed choice among the many assay options available for use in regulatory and management programs. Our results showed that the analytical sensitivity of " $\mathrm{Ca}$. Liberibacter spp." detection in plant tissues using the TaqMan real-time PCR system could be increased by 1 to $2 \log$ units over the conventional PCR system. Thus, the TaqMan real-time protocol has the potential to become a valuable tool for early detection of " $\mathrm{Ca}$. Liberibacter spp." prior to the appearance of disease symptoms. Reliable, robust, and unambiguous identification of " $\mathrm{Ca}$. Liberibacter spp." is greatly needed for an effective regulatory response, to facilitate management of infected trees, and to contribute toward the development of " $\mathrm{Ca}$. Liberibacter spp."-free certified plant materials.

\section{MATERIALS AND METHODS}

Plant materials. For the detection of Las in asymptomatic or symptomatic plant materials, leaves were collected from 76 sweet orange (Citrus sinensis) seedling 
trees from the Exotic Pathogens of Citrus Collection (EPCC), USDA-ARS, Beltsville, MD. These seedling trees included 48 trees previously grafted with buds from Asiatic HLB sources, 17 of which were symptomatic. Twenty-eight trees previously grafted with other sources of grafttransmitted pathogens, including Citrus psorosis virus, Citrus ringspot virus, and Citrus tristeza virus, served as negative controls for " $\mathrm{Ca}$. L. asiaticus". Assay performance was evaluated using twigs and leaves with blotchy mottle symptoms received from field-grown suspected HLBinfected citrus plants collected in Florida. Materials for the early detection of Las Florida strains were generated by grafting HLB-positive twigs collected from Florida onto Citrus hystrix, common sweet orange (Citrus sinensis), and Ridge Pineapple ( $C$. sinensis) in a biosecurity level 3 (BSL3) greenhouse at the National Plant Germplasm and Biotechnology Laboratory (NPGBL), USDA-APHIS, Beltsville, MD. Leaves were collected from these plants for Las detection at several times postinoculation. In addition, three twigs with 5 to 10 mottled leaves each collected from one plant experimentally inoculated by grafting with Laf Nelspruit, Letaba, or Stellenbosch strains in a greenhouse, and from one plant infected with Laf ITSC strain in the field at the Institute for Tropical and Subtropical Crops in Nelspruit, South Africa, were sent to the Fruit Laboratory, USDA-ARS, Beltsville, MD.

DNA isolation. Total DNA was isolated at NPGBL, using the DNeasy Plant Mini kit (Qiagen, Valencia, CA), from midrib tissues of field-grown plants from Florida and from greenhouse-grown plants healthy and inoculated with Las Florida strains. DNA extraction of the greenhouse-grown plant materials from EPCC (including plants inoculated with Las, other citrus pathogens or citrus endophytes), and of the HLB-infected plant materials from South Africa was each extracted using the DNeasy Plant Mini kits, at the Fruit Laboratory USDA-ARS in Beltsville, MD. Total DNA samples kindly provided by Diva C. Teixeira (Fundecitrus, São Paulo, Brazil) were extracted in Brazil using a CTAB method (20) from $500 \mathrm{mg}$ of midribs of symptomatic or asymptomatic leaves of field-grown sweet orange trees. DNA samples kindly provided by Toru Iwanami (National Agricultural Research Center, Kumamoto, Japan) were also extracted using the CTAB method from midrib tissues of HLB symptomatic leaves of greenhouse-grown rough lemon (C. jambhiri).
Conventional PCR. To assure good assay performance, sensitivity, specificity, and reproducibility of four conventional PCR protocols used to detect HLB pathogens were validated in this study. The primer sets used in the PCR reactions were the $16 \mathrm{~S}$ rDNA primer sets, OI1/OI2c (reported to be specific to Las), OA1/OI2c (reported to be specific to Laf) (13), GB1/GB3 (reported to be specific to Lam) (27), and the $\beta$-operon primer set A2/J5 (reported to be specific to both Las and Laf) (10). Reagent optimization was conducted to identify the most suitable concentration for $\mathrm{MgCl}_{2}$, dNTPs, and primers; while standardizing the physical parameters of the protocols identified the best temperature and time for each step of the PCR. The optimization and standardization were carried out with 10-fold dilutions of total DNA samples obtained from fieldgrown plants infected with Las 13600 from Florida, Lam 967 from Brazil, and Laf ITSC from South Africa (data not shown). The PCR reactions were performed using a PTC-200 Peltier Thermal Cycler (MJ Research, Inc., Watertown, MA) in a $25-\mu l$ reaction volume consisting of the following reagents at the optimized concentrations: $200 \mathrm{nM}$ (each) primer, $200 \mu \mathrm{M}$ (each) dNTPs, $2.5 \mathrm{mM} \mathrm{MgCl} 2$, $1 \times$ PCR

Table 1. Specificity of DNA amplification methods for detection and identification of "Candidatus Liberibacter species" associated with citrus huanglongbing

\begin{tabular}{|c|c|c|c|c|c|c|c|c|c|c|c|}
\hline \multirow{3}{*}{$\begin{array}{l}\text { Species } \\
\text { Strain or isolate }\end{array}$} & \multirow[b]{3}{*}{ Host } & \multirow[b]{3}{*}{ Provider } & \multirow[b]{3}{*}{ Origin } & \multicolumn{4}{|c|}{ Conventional PCR ${ }^{a}$} & \multirow{2}{*}{\multicolumn{3}{|c|}{ Real-time PCR (FAM Ct values) ${ }^{\mathrm{a}}$}} & \multirow[b]{3}{*}{$\mathbf{L A M P b}$} \\
\hline & & & & \multirow{2}{*}{$\begin{array}{l}\text { OI1/ } \\
\text { OI2c }\end{array}$} & \multirow{2}{*}{$\begin{array}{l}\text { OA1/ } \\
\text { OI2c }\end{array}$} & \multirow{2}{*}{$\begin{array}{l}\text { A2/ } \\
\text { J5 }\end{array}$} & \multirow{2}{*}{$\begin{array}{l}\text { GB1/ } \\
\text { GB3 }\end{array}$} & & & & \\
\hline & & & & & & & & HLBaspr & HLBafpr & $\overline{\text { HLBampr }}$ & \\
\hline \multicolumn{12}{|c|}{ "Candidatus Liberibacter asiaticus" } \\
\hline Strain B239 & Citrus sp. & Hartung, J. S. & Taiwan & + & + & + & - & 22.51 & 34.47 & 0 & + \\
\hline Strain KIN1 & Citrus sp. & Iwanami, $\mathrm{T}$. & Japan & + & + & + & - & 25.26 & 37.28 & 0 & + \\
\hline Strain IDN5 & Citrus sp. & Iwanami, $\mathrm{T}$. & Indonesia & + & + & + & - & 26.32 & 38.15 & 0 & + \\
\hline Strain Las 892 & Citrus sp. & Teixeira, D. C. & Brazil & + & + & + & - & 21.61 & 33.45 & 0 & + \\
\hline Strain Las 13600 & Citrus sp. & Gottwald, T. & U.S. Florida & + & + & + & - & 19.89 & 31.78 & 0 & + \\
\hline \multicolumn{12}{|l|}{ "Candidatus L. africanus" } \\
\hline Strain Letaba & Citrus sp. & Van Vuuren, F. & S. Africa & + & + & + & - & 37.35 & 30.40 & 0 & + \\
\hline Strain Stellenbosch & Citrus sp. & Van Vuuren, F. & S. Africa & + & + & + & - & 42.85 & 33.74 & 0 & + \\
\hline Strain ITSC & Citrus sp. & Van Vuuren, F. & S. Africa & + & + & + & - & 40.34 & 31.53 & 0 & + \\
\hline \multicolumn{12}{|c|}{ "Candidatus L. americanus" } \\
\hline Strain Lam 974 & Citrus sp. & Teixeira, D. C. & Brazil & - & - & - & + & 0 & 0 & 23.67 & - \\
\hline Strain Lam 975 & Citrus sp. & Teixeira, D. C. & Brazil & - & - & - & + & 0 & 0 & 22.65 & - \\
\hline Strain Lam 976 & Citrus sp. & Teixeira, D. C. & Brazil & - & - & - & + & 0 & 0 & 24.11 & - \\
\hline Strain Lam 977 & Citrus sp. & Teixeira, D. C. & Brazil & - & - & - & + & 0 & 0 & 24.43 & - \\
\hline Strain Lam 978 & Citrus sp. & Teixeira, D. C. & Brazil & - & - & - & + & 0 & 0 & 23.81 & - \\
\hline $\begin{array}{l}\text { Xylella fastidiosa CVC } \\
\text { strain L001 } \\
\text { Xanthomonas axonopodis }\end{array}$ & Citrus sp. & Hartung, J. S. & Brazil & - & - & - & - & 0 & 0 & 0 & - \\
\hline $\begin{array}{l}\text { pv. citri strain A } \\
\text { Phytophthora citricola }\end{array}$ & Citrus sp. & Mavrodieva & U.S. Florida & - & - & - & - & 0 & 0 & 0 & - \\
\hline $\begin{array}{l}\text { I } 22 \mathrm{~F} 3 \\
\text { Phytophthora citrophthor }\end{array}$ & Citrus sp. & Mavrodieva & Unknown & - & - & - & - & 0 & 0 & 0 & - \\
\hline $\begin{array}{l}\text { I 1E4 } \\
\text { Methylobacterium }\end{array}$ & Citrus sp. & Mavrodieva & Brazil & - & - & - & - & 0 & 0 & 0 & - \\
\hline $\begin{array}{l}\text { mesophilicum SR1.6/6 } \\
\text { Curtobacterium }\end{array}$ & Citrus sp. & Hartung, J. S. & Brazil & - & - & - & - & 0 & 0 & 0 & - \\
\hline $\begin{array}{c}\text { flaccumfaciens ER1/6 } \\
\text { Citrus tristeza virus/total }\end{array}$ & Citrus sp. & Hartung, J. S. & Brazil & - & - & - & - & 0 & 0 & 0 & - \\
\hline $\begin{array}{l}\text { plant DNA } \\
\text { Citrus blight/total plant }\end{array}$ & Citrus sp. & Hartung, J. S. & U.S. Florida & - & - & - & - & 0 & 0 & 0 & - \\
\hline $\begin{array}{l}\text { DNA } \\
\text { Citrus sudden death/total }\end{array}$ & Citrus sp. & Hartung, J. S. & U.S. Florida & - & - & - & - & 0 & 0 & 0 & - \\
\hline plant DNA & Citrus sp. & Hartung, J. S. & Brazil & - & - & - & - & 0 & 0 & 0 & - \\
\hline
\end{tabular}

a OI1/OI2c, OA1/OI2c (13), GB1/GB3 (27), and HLBaspr, afpr, ampr (16) are 16S rDNA-based primers or probes; A2/J5 are $\beta$-operon-based primers (10).

$\mathrm{b}$ The primers used in LAMP were 16S rDNA-based rdna-F3, rdna-B3, rdna-FIP, and rdna-BIP (22). 
buffer, and 1 unit Platinum Taq polymerase (Invitrogen, Carlsbad, CA). The optimized amplification protocol (for all primer sets, OI1/OI2c, OA1/OI2c, GB1/GB3, and A2/J5) was $94^{\circ} \mathrm{C}$ for 2 min followed by 35 cycles of $94^{\circ} \mathrm{C}$ for $30 \mathrm{~s}, 62^{\circ} \mathrm{C}$ for $30 \mathrm{~s}$, and $72^{\circ} \mathrm{C}$ for $1 \mathrm{~min}$, followed by a final extension cycle of $10 \mathrm{~min}$ at $72^{\circ} \mathrm{C}$. Following electrophoresis using $1.0 \%$ agarose gels, PCR products were visualized by staining with ethidium bromide. When assays were conducted to compare the relative sensitivities of standard format- and real timePCR for pathogen detection, DNA extracts of infected plants were diluted with a similar DNA extract prepared from a healthy plant to maintain a constant total DNA concentration of $50 \mu \mathrm{g} / \mathrm{ml}$. This was done to prevent target DNA from being lost in the dilution series due to nonspecific binding to labware and to provide uniform conditions in all amplification reactions (16).

Real-time PCR. Quantitative real-time PCR assays with the target primer-probe sets, HLBaspr, HLBafpr, and HLBampr, plus an internal amplification control using the plant cytochrome oxidase (COX)-based primer-probe set (COXfpr) were performed as reported previously (16) in a SmartCycler II (Cepheid, Sunnyvale, CA).
All reactions were performed in duplicate, and each run contained one negative and one positive control. The mean $\mathrm{Ct}$ values were analyzed using the SmartCycler software version 2.0D.

LAMP. LAMP reactions were conducted as reported (22), in $25 \mu \mathrm{l}$ of mixture containing $1 \times$ reaction buffer, $4.0 \mathrm{mM}$ $\mathrm{MgCl}_{2}, 1.0 \mathrm{M}$ betaine, $200 \mu \mathrm{M}$ (each) dNTPs, $0.2 \mu \mathrm{M}$ each of rdna-F3 and rdnaB3 primers, $0.8 \mu \mathrm{M}$ each of rdna-FIP and rdna-BIP primers, and $2 \mu \mathrm{l}$ of the total DNA samples. The mixture was then incubated at $95^{\circ} \mathrm{C}$ for $5 \mathrm{~min}$ before $8 \mathrm{U}$ of $B s t$ DNA polymerase (New England Biolabs, Beverly, MA) was added followed by incubation at $65^{\circ} \mathrm{C}$ for $1 \mathrm{~h}$ and $80^{\circ} \mathrm{C}$ for 10 min. Following electrophoresis through $1.0 \%$ agarose gels, LAMP products were visualized by staining with ethidium bromide.

\section{RESULTS}

Specificity comparison. As shown in Table 1 and Figure 1, the 16s rDNA primer sets OI1/OI2c and OA1/OI2c (13) and the $\beta$-operon primer set A2/J5 (10) detected all Asian (Las) and African (Laf) strains (except the Nelspruit strain) but none of the Brazilian (Lam) strains. Conversely, the 16s rDNA primer set GB1/GB3 (27) de- tected only the Lam strains, and not the Las or Laf strains. Among the primerprobe sets used in real-time PCR assays, HLBaspr and HLBafpr detected the Las and Laf strains, respectively, as expected. HLBaspr also detected the Laf strains, and HLBafpr also detected the Las strains but with $\mathrm{Ct}$ values substantially higher than those produced by the homologous probes (Table 1). Neither HLBaspr nor HLBafpr detected any of the Lam strains tested. As expected, HLBampr did not detect either the Las or Laf strains, but it did detect the Lam strains. The LAMP assay (22) detected all Las and Laf strains, but not the Lam strains. None of the primer or primerprobe sets above had any cross-reactivity with other citrus pathogens including a citrus strain of Xylella fastidiosa, a Xanthomonas axonopodis pv. citri strain A, Phytophthora citricola I 22F3, and $P$. citrophthora I 1E4. They also did not amplify any products from total DNA extracts of plants affected by citrus tristeza, citrus sudden death, or citrus blight. Additionally, none of the primer-probe sets cross-reacted with citrus endophytes such as Methylobacterium mesophilicum SR1.6/6 and Curtobacterium flaccumfaciens ER1/6.

Sensitivity comparison. There were no significant differences of sensitivity among

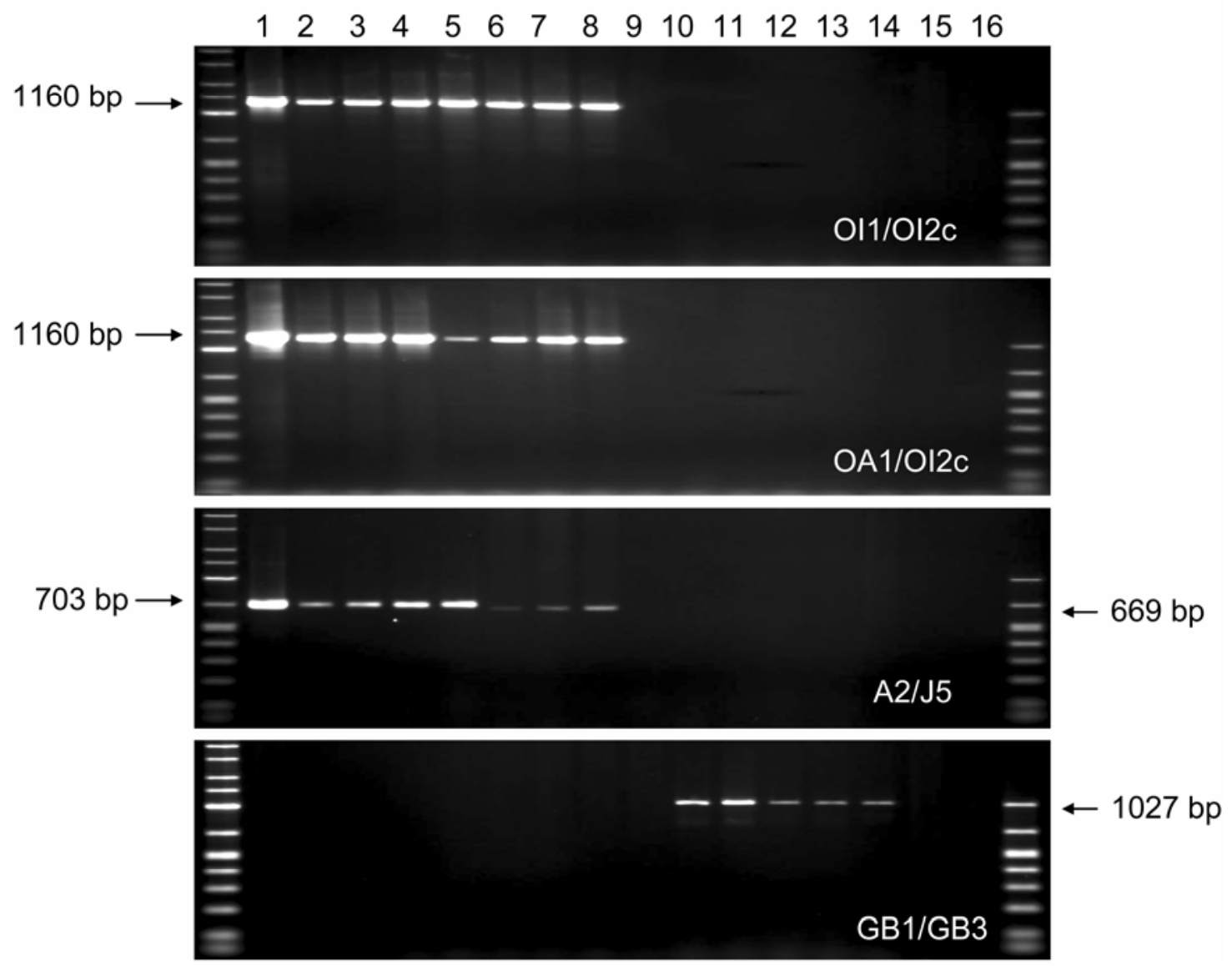

Fig. 1. Amplification of genomic DNA of "Candidatus Liberibacter spp." with primers sets OI1/OI2c, OA1/OI2c (13), A2/J5 (10), and GB1/GB3 (27). The left and right outside lanes contain BioMarker EXT PLUS and Low, respectively (BioVentures, Inc., Murfreesboro, TN). Lanes 1 to 14 are "Ca. L. asiaticus" strains B239, KIN1, IDN5, BR892, and FL136; “Ca. L. africanus” strains Letaba, Stellenbosch, ITSC, and Nelspruit; Lam strains BR974, BR975, BR976, BR977, and BR 978. Lane 15 contains DNA from a healthy sweet orange and lane 16 contains the no-template control. 
the conventional PCR assays using the primer sets $\mathrm{OI} 1 / \mathrm{OI} 2 \mathrm{c}$ or $\mathrm{A} 2 / \mathrm{J} 5$ for Las (Fig. 2), OA1/OI2c or A2/J5 for Laf (Fig. 3), and GB1/GB3 for Lam (Fig. 4). The conventional PCR with these primer sets detected " $C a$. Liberibacter spp." in $1 \mu \mathrm{l}$ of the $10^{-2}$ dilutions of $200 \mu \mathrm{l}$ of DNA extracts obtained using Qiagen kits or from the CTAB method using $200 \mathrm{mg}$ of midrib tissues from HLB symptomatic citrus leaves. However, real-time PCR assays reproducibly detected the " $\mathrm{Ca}$. Liberibacter spp." strains in the $10^{-2}$ through $10^{-5}$ dilutions of DNA extracts obtained from plants infected by Las in Florida (Fig. 2), Laf in South Africa (Fig. 3), and Lam in Brazil (Fig. 4), respectively.

The differences in sensitivity between conventional and real-time PCR assays were confirmed further by early detection of a Las strain from Florida in greenhousegrown plants experimentally inoculated by grafting (Table 2). Real-time PCR detected the Las strain in asymptomatic young leaves of common sweet orange at 30 days and of Ridge Pineapple sweet orange and $C$. hystrix at 60 days postinoculation, although with relatively high $\mathrm{Ct}$ values. Conventional PCR with primers OI1/OI2c or A2/J5 reproducibly detected the Las strain in asymptomatic leaves of sweet orange, Ridge Pineapple, and C. hystrix 90 days postinoculation.

The internal control primer-probe set COXfpr, which was designed on the basis of the conserved sequence of a cytochrome oxidase (COX) gene in citrus plants (16), could detect plant DNA in dilutions as low as $10^{-6}$ and confirm the quality of the total DNA extracts obtained from plants infected with " $\mathrm{Ca}$. Liberibacter spp." (Fig. 3).

Assay performance. To evaluate the performance of DNA amplification meth- ods for detection of " $\mathrm{Ca}$. Liberibacter spp.", 336 DNA extracts obtained from 204 HLB suspect, symptomatic, or healthy citrus plants were used (Table 3). Among these 204 plants, 126 showed foliar symptoms consistent with HLB and 78 were asymptomatic. All 17 HLB symptomatic greenhouse-grown plants experimentally inoculated with " $\mathrm{Ca}$. L. asiaticus" by grafting tested positive for the pathogen by conventional PCR assays with the primer sets OI1/OI2c and A2/J5, and by real-time PCR with the primer-probe set HLBaspr. However, the pathogen was not detected by LAMP in three of these symptomatic plants. All 63 asymptomatic greenhousegrown plants tested negative for " $\mathrm{Ca}$. L. asiaticus" by conventional PCR. However, one of these plants tested positive for the pathogen by real-time PCR. LAMP yielded positive results for six of these asymptomatic plants. Because two of these

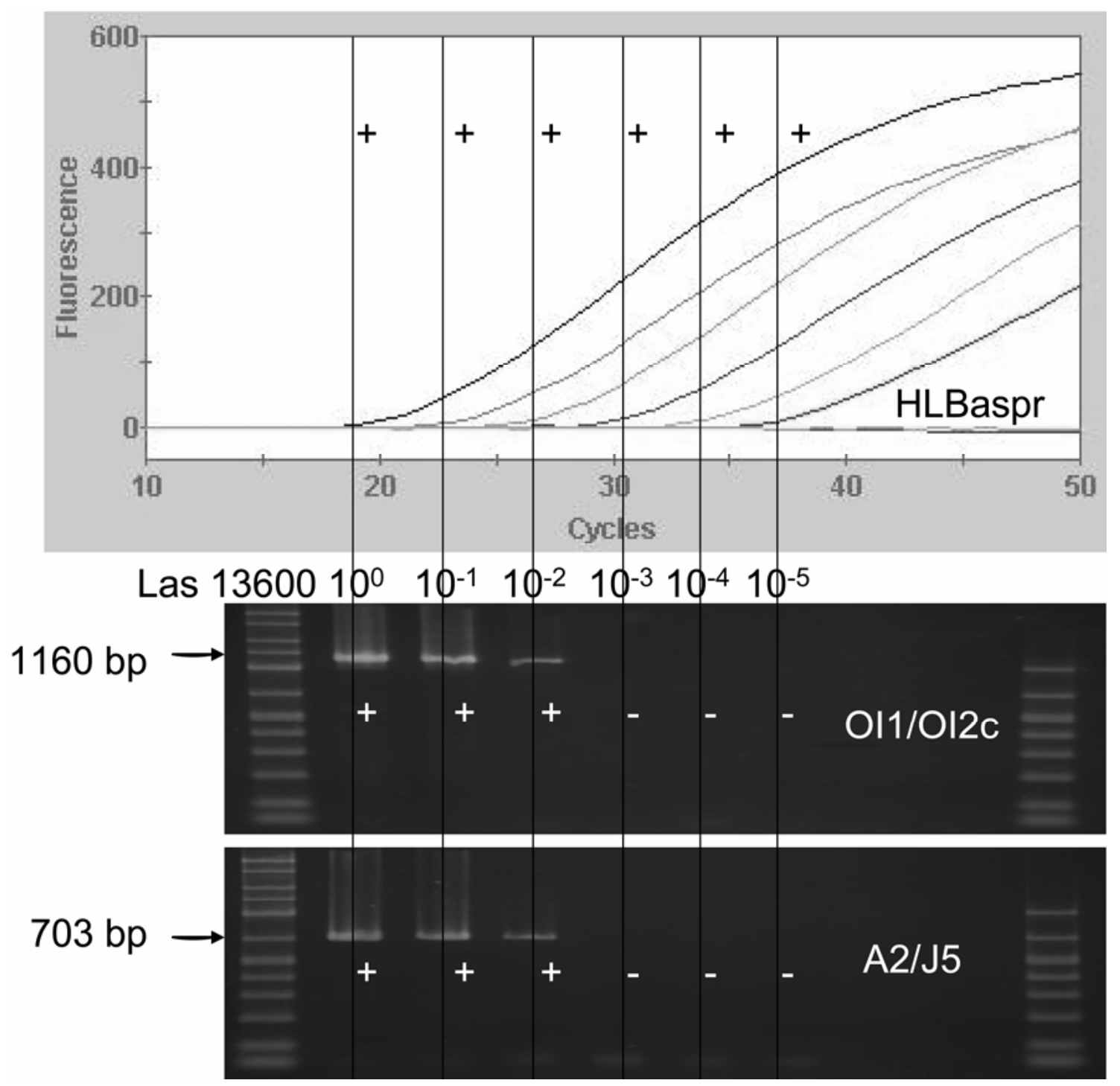

Fig. 2. Sensitivity comparison between multiplex real-time polymerase chain reaction (PCR) with the primer-probe set HLBaspr specific to "Candidatus Liberibacter asiaticus", and the positive internal control primer-probe set COXfpr (16) and conventional PCR with the primer sets OI1/OI2c (13) and A2/J5 (10). Serial dilutions of a DNA sample obtained from a field-grown, huanglongbing symptomatic pummelo (Citrus maxima) tree infected with Florida strain Las 13600 of " $\mathrm{Ca}$. L. asiaticus" were used as template. Dilutions were made with a DNA sample obtained from a healthy sweet orange and contained about $50 \mu \mathrm{g} / \mathrm{ml}$ of total plant DNA. 
trees had not previously been inoculated with " $C a$. Liberibacter spp.", but rather with other graft-transmitted pathogens, we attribute these LAMP results to contamination of the reactions, probably when the Bst polymerase was added to each tube.

Among 172 DNA extracts obtained from 86 field-grown plants showing HLB symptoms, 156 DNA extracts tested positive and 16 negative for " $\mathrm{Ca}$. L. asiaticus" by both conventional and real-time PCR assays. None of 24 DNA extracts obtained from 12 asymptomatic and healthy field-grown plants tested positive for " $\mathrm{Ca}$. Liberibacter spp." by either conventional or real-time PCR assays.

All DNA extracts obtained from greenhouse- and field-grown symptomatic plants from South Africa tested positive for
"Ca. L. africanus" by both conventional and real-time PCR assays. None of 11 DNA extracts obtained from asymptomatic leaves of a single greenhouse-grown plant experimentally inoculated with " $\mathrm{Ca}$. L. africanus" in South Africa tested positive for the pathogen by either conventional or real-time PCR assays. This plant had heavy stem pitting caused by Citrus tristeza virus, and may not have been infected by " $\mathrm{Ca}$. L. africanus".

The DNA extracts obtained from 20 HLB-symptomatic, field-grown plants infected by " $\mathrm{Ca}$. L. americanus" in São Paulo, Brazil tested positive for the pathogen by both conventional and real-time PCR assays. DNA extracts from two healthy fieldgrown citrus plants from Brazil were negative for " $\mathrm{Ca}$. Liberibacter spp."

\section{DISCUSSION}

The causal agent of HLB was first discovered in Florida in August 2005, and was further identified as a " $\mathrm{Ca}$. L. asiaticus" strain based on real-time PCR assays using specific primer-probe sets (16) and conventional PCR assays with additional PCR product digestion with $\mathrm{XbaI}$ (data not shown). As confirmed in this study, " $\mathrm{Ca}$. Liberibacter spp." can be distinguished by either conventional $(10,12,13,28)$ or realtime (16) PCR assays. Asian strains can also be distinguished from African strains on the basis of their tolerance to high temperature and the cleavage patterns of $16 \mathrm{~S}$ rDNA PCR fragments when digested with $X b a \mathrm{I}$ (13). However, the restriction digestion method is time-consuming and inconvenient for rapid differentiation of the


Fig. 3. Sensitivity comparison between multiplex real-time polymerase chain reaction (PCR) with the primer-probe set HLBafpr specific to "Candidatus Liberibacter africanus" and the positive internal control primer-probe set COXfpr (16), versus conventional PCR with the primer sets OA1/OI2c (13) and A2/J5 (10). Serial dilutions of a DNA sample obtained from a field-grown, huanglongbing symptomatic sweet orange tree infected with a strain "Ca. L. africanus" ITSC of "Ca. L. africanus" in Delta Valencia, South Africa were used as template. Dilutions were made with a DNA sample obtained from a healthy sweet orange and contained about $50 \mu \mathrm{g} / \mathrm{ml}$ of total plant DNA. 
Asian species from the African where mixed infections are endemic.

Although the $16 \mathrm{~S}$ rDNA primer set OI1/OI2c was designed to be specific to Ca. L. asiaticus, PCR assays with this primer set cross-reacted with " $\mathrm{Ca}$. L. africanus" strains $(12,13)$. Another $16 \mathrm{~S}$ rDNA primer set OA1/OI2c was designed to be specific to " $\mathrm{Ca}$. L. africanus". Similarly, PCR using this primer set cross-reacted and amplified 16s rDNA of " $\mathrm{Ca}$. L. asiaticus" obtained by one DNA extraction protocol, but not that by another extraction protocol (13). These two conventional PCR systems have been optimized for 16S rDNA in this study. However, PCR amplification by the two systems each yields a band of $1,160 \mathrm{bp}$ at the same intensity for all strains of " $\mathrm{Ca}$. L. asiaticus" and " $\mathrm{Ca}$. L. africanus" when total DNA extracts obtained using Qiagen DNA extraction kits were used (Fig. 1). The two primer sets use the same reverse primer OI2c, and the specificity of amplification is based on the forward primers. There are only three SNPs between the priming sites of the forward primers OI1 and OA1, and these SNPs are clustered in the middle of the primer binding sites. The clustered SNP structure in the forward primers may cause a hairpin conformation when the primers mismatch with the template DNA of the different " $\mathrm{Ca}$. Liberibacter spp." strains and may explain the unanticipated amplification of heterologous targets.

"Ca. L. asiaticus" and "Ca. L. africanus" can be differentiated by the size of amplicons obtained by conventional PCR with the $\beta$-operon primer set A2/J5 (10). There is a difference of $34 \mathrm{bp}$ in size between the $\beta$-operon PCR fragments obtained from "Ca. L. asiaticus" and "Ca. L. africanus". The real-time PCR with specific primer-probe sets HLBaspr and HLBafpr also differentiates " $\mathrm{Ca}$. L. asiaticus" from "Ca. L. africanus", not by size but by $\mathrm{Ct}$ values, as shown in Table 1 . Since all current PCR primers and probes are based upon only a few genetic loci, the ongoing " $\mathrm{Ca}$. Liberibacter spp." genome project will assist in the design and validation of additional potential species-specific primer and/or probe sets, when it has progressed further.

In HLB field surveys, foliar blotchy mottle and lopsided fruit are used to iden- tify symptomatic plants. Even though these symptoms are characteristic of HLB, neither is unique to the disease (13). The population threshold of " $\mathrm{Ca}$. Liberibacter spp." needed to induce these symptoms is usually high (16), and it is impossible to identify any asymptomatic infected plants simply by observation during an HLB field survey. The conventional and real-time PCR assays validated in this study are being used currently for HLB diagnosis, including primary and confirmatory tests for the HLB surveys occurring in Florida. The sensitivity, reliability, and speed of these assays are critical for appropriate management of the disease.

It is difficult to determine the sensitivity of any diagnostic method for detection of HLB pathogens since the bacteria are nonculturable on artificial media. A method that blended infected plant tissues with healthy plant tissue was used previously to evaluate the sensitivity of conventional PCR assays with the primer sets OI1/OI2c or OA1/OI2c or OI1/OA1/OI2c $(10,13)$. In this study, the conventional PCR assays could detect " $\mathrm{Ca}$. Liberibacter spp." in 2 to $10 \mu \mathrm{l}$ of $100 \mu \mathrm{l}$ of the original DNA ex-

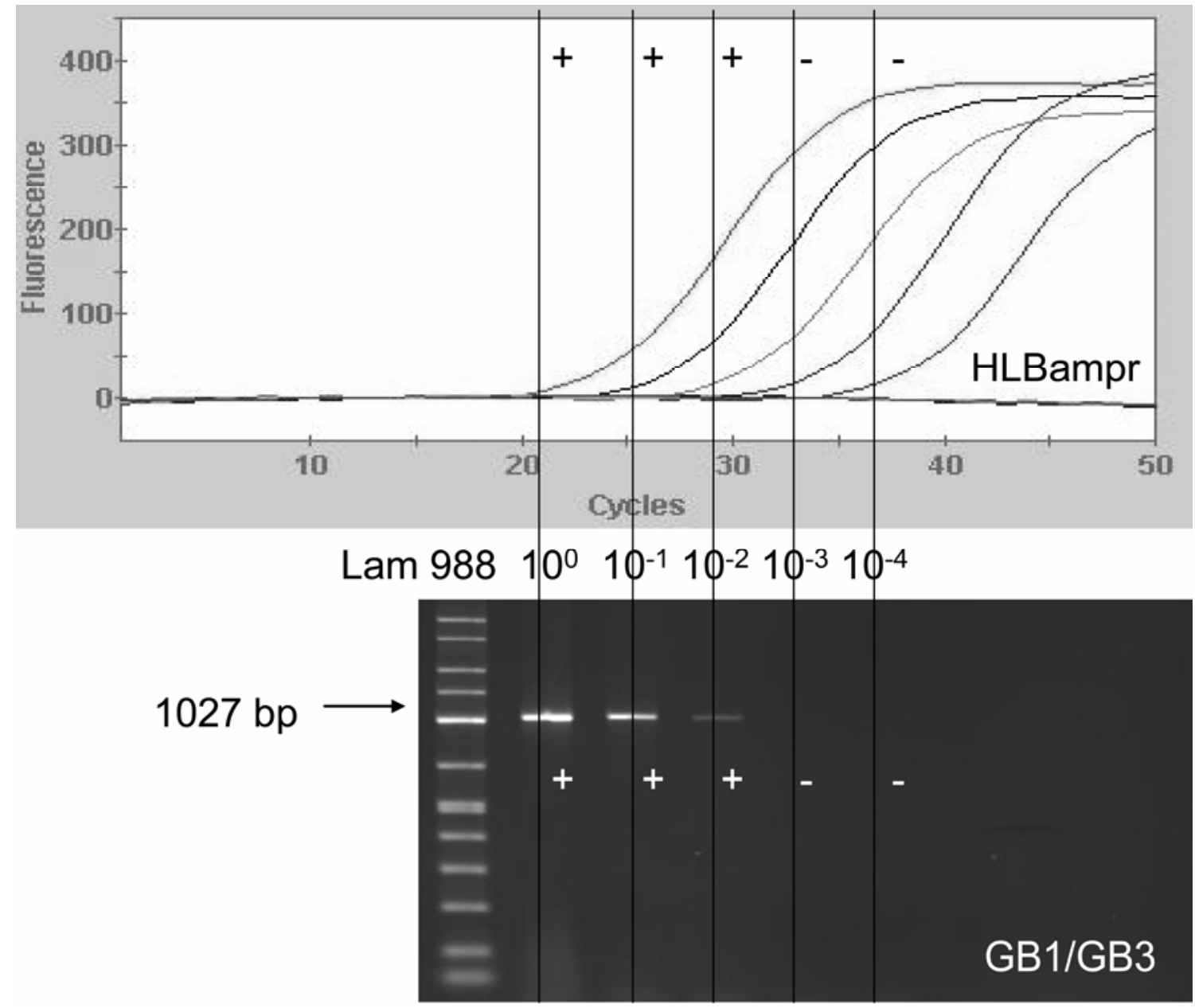

Fig. 4. Sensitivity comparison between multiplex real-time polymerase chain reaction (PCR) with the primer-probe set HLBampr specific to "Candidatus Liberibacter americanus" and the positive internal control primer-probe set COXfpr (16) and conventional PCR with the primer set GB1/GB3 (27). Serial dilutions of a DNA sample obtained from a field-grown, huanglongbing symptomatic sweet orange tree infected with São Paulo strain Lam 988 of " $\mathrm{Ca}$. L. americanus" were used as template. Dilutions were made with a DNA sample obtained from a healthy sweet orange and contained about $50 \mu \mathrm{g} / \mathrm{ml}$ of total plant DNA. 
tracts obtained from mixed samples made of $1 \mathrm{~g}$ of healthy midribs with a minimum of $20 \mathrm{mg}$ of infected midribs. The lower limit of " $\mathrm{Ca}$. Liberibacter spp." detection of the original protocols was equivalent to $0.4 \mathrm{mg}$ of infected midribs $(20 \mathrm{mg} \div 100$ $\mu \mathrm{l}$ of elution $\times 2 \mu \mathrm{l}$ of DNA per PCR reaction). Serial dilutions of DNA extracts from infected plant tissues in DNA extracts from healthy plant tissues were used to determine the sensitivity of the optimized and validated protocols of conventional PCR with the same two primers sets. " $\mathrm{Ca}$. Liberibacter spp." were detected reliably in $1 \mu \mathrm{l}$ of the $10^{-2}$ dilutions of $200 \mu \mathrm{l}$ of the original DNA extracts, obtained from 200 $\mathrm{mg}$ of midrib tissues from symptomatic leaves using Qiagen kits (Figs. 2 to 4 ). The lower detection limit of the validated protocols was equivalent to $0.01 \mathrm{mg}$ of in- fected midribs per reaction. The sensitivity of the validated conventional PCR protocols was improved for HLB diagnosis over that of the original protocols $(10,13,27)$.

The DNeasy Plant Mini Kit from Qiagen is among the best DNA extraction methods for citrus pathogens from citrus plants (15). Since the kit has a maximum capacity for sample materials $(\leq 100 \mathrm{mg}$ wet weight), it was difficult in this study to employ blended samples of plant materials to determine sensitivity as in the original conventional PCR protocols (13). Instead, we used 10-fold serial sample (DNA extract) dilutions for both conventional and real-time PCR assays as a basis for comparing sensitivity in this study. In previous work, the increased amount $(>1.2 \mathrm{~g})$ of plant materials sampled did not increase the DNA yields of the kit. Instead, it de-

Table 2. Real-time and conventional polymerase chain reaction (PCR) for early detection of a Florida strain of "Candidatus Liberibacter asiaticus"

\begin{tabular}{llcccc}
\hline & & \multicolumn{4}{c}{ Days postinoculation $^{\mathbf{b}}$} \\
\cline { 3 - 6 } Plants inoculated & Detection methods & $\mathbf{3 0}$ & $\mathbf{6 0}$ & $\mathbf{9 0}$ & $\mathbf{1 2 0}$ \\
\hline Sweet orange & Symptoms & No & No & Yes & Yes \\
& Ct values of real-time PCR & 35.16 & 32.68 & 17.68 & 16.85 \\
& Conventional PCR with OI1/OI2c & - & - & + & + \\
Ridge pineapple & Conventional PCR with A2/J5 & - & - & + & + \\
sweet orange & Symptoms & No & No & No & Yes \\
& Ct values of real-time PCR & 0 & 34.24 & 30.35 & 19.49 \\
& Conventional PCR with OI1/OI2c & - & - & + & + \\
C. hystrix & Conventional PCR with A2/J5 & - & - & + & + \\
& Symptoms & No & No & No & No \\
& Ct values of real-time PCR & 0 & 35.06 & 31.32 & 20.14 \\
& Conventional PCR with OI1/OI2c & - & - & + & + \\
& Conventional PCR with A2/J5 & - & - & + & + \\
\hline
\end{tabular}

${ }^{a}$ Three leaves were sampled for DNA extraction from each of three inoculated plants for each host. The primer-probe set HLBaspr and COXfpr were used in real-time PCR (16).

${ }^{\mathrm{b}} \mathrm{OI} 1 / \mathrm{OI} 2 \mathrm{c}(13)$ and HLBaspr (16) are $16 \mathrm{~S}$ rDNA-based primers or probes; A2/J5 are $\beta$-operon-based primers $(10) .+=$ positive for the pathogen; $-=$ negative for the pathogen .

creased the DNA extraction efficiency. This may be part of the reason why there were significant differences in sensitivity between the original (13) and our validated conventional PCR systems.

In our previous study, " $\mathrm{Ca}$. Liberibacter spp." were detected successfully by TaqMan real-time PCR from the equivalent of $20 \mathrm{ng}$ of midribs from symptomatic leaves (16). In this study, results showed the real-time PCR was up to 1,000 -fold (Fig. 2) more sensitive than the validated conventional PCR for " $\mathrm{Ca}$. Liberibacter spp." detection. The differences in sensitivity between the TaqMan real-time and conventional PCR assays are probably due to increased amplification efficiency because of the smaller amplicon sizes of the TaqMan assay and its lower vulnerability to PCR inhibitors from citrus plants $(9,15)$. There were also differences in detection sensitivity found among the real-time PCR assays for different " $\mathrm{Ca}$. Liberibacter spp." (Figs. 2 to 4 ). These differences may be due to primer design, the pathogen DNA, or inhibitors from host plants.

Four conventional and three real-time PCR assay systems gave concordant results in the comprehensive performance evaluation (Table 3). The greenhousegrown plants used in this study had been inoculated experimentally more than 3 years before leaf samples were taken. The $\mathrm{Ct}$ values of real-time PCR assays for 17 "Ca. L. asiaticus"-positive and two " $\mathrm{Ca}$. L. africanus"-positive plants showed that the "Ca. Liberibacter spp." populations in these plants were in the region of overlap for the detection ranges for both the conventional and the real-time PCR assays (data not shown). Similarly, all 78 " $\mathrm{Ca}$. L. asiaticus"-positive, 1 "Ca. L. africanus"-

Table 3. Performance of DNA amplification methods for detection of "Candidatus Liberibacter species" associated with citrus huanglongbing

\begin{tabular}{|c|c|c|c|c|c|c|c|c|c|c|c|}
\hline \multirow[b]{3}{*}{ Pathogens } & \multirow{3}{*}{$\begin{array}{l}\text { Source of DNA } \\
\text { extracts }\end{array}$} & \multirow{3}{*}{$\begin{array}{c}\text { Disease } \\
\text { symptoms }\end{array}$} & \multirow{3}{*}{$\begin{array}{l}\text { No. of } \\
\text { DNA } \\
\text { extracts }\end{array}$} & \multicolumn{4}{|c|}{ Conventional PCR ${ }^{\mathrm{a}}$} & \multirow{2}{*}{\multicolumn{3}{|c|}{ Real-time PCR }} & \multirow[b]{3}{*}{$\mathbf{L A M P}^{\mathbf{b}}$} \\
\hline & & & & \multirow{2}{*}{$\begin{array}{l}\text { OI1/ } \\
\text { OI2c }\end{array}$} & \multirow{2}{*}{$\begin{array}{l}\text { OA1/ } \\
\text { OI2c }\end{array}$} & \multirow{2}{*}{$\begin{array}{l}\text { A2/ } \\
\text { J5 }\end{array}$} & \multirow{2}{*}{$\begin{array}{l}\text { GB1/ } \\
\text { GB3 }\end{array}$} & & & & \\
\hline & & & & & & & & HLBaspr & HLBafpr & HLBampr & \\
\hline \multirow{8}{*}{$\begin{array}{l}\text { "Candidatus } \\
\text { Liberibacter asiaticus" }\end{array}$} & 80 Greenhouse-grown & 17 (Yes) & 17 & $17(+)$ & I & $17(+)$ & I & $17(+)$ & I & I & $14(+)$ \\
\hline & plants (U.S. and & & & $0(-)$ & 1 & $0(-)$ & 1 & $0(-)$ & 1 & l & $3(-)$ \\
\hline & Japan) & $63(\mathrm{No})$ & 63 & $0(+)$ & I & $0(+)$ & I & $1(+)$ & I & 1 & $6(+)$ \\
\hline & & & & $63(-)$ & I & $63(-)$ & I & $62(-)$ & I & I & $57(-)$ \\
\hline & 98 Field-grown plants & 86 (Yes) & 172 & $156(+)$ & I & $156(+)$ & I & $156(+)$ & I & I & I \\
\hline & (U.S. and Brazil) & & & $16(-)$ & I & $16(-)$ & I & $16(-)$ & l & I & I \\
\hline & & $12(\mathrm{No})$ & 24 & $0(+)$ & 1 & $0(+)$ & l & $0(+)$ & I & l & l \\
\hline & & & & $24(-)$ & I & $24(-)$ & I & $24(-)$ & I & I & 1 \\
\hline \multirow{6}{*}{$\begin{array}{l}\text { "Candidatus } \\
\text { L. africanus" }\end{array}$} & 3 Greenhouse-grown & 2 (Yes) & 15 & i & $15(+)$ & $15(+)$ & l & i & $15(+)$ & I & l \\
\hline & plants (South Africa) & & & I & $0(-)$ & $0(-)$ & I & I & $0(-)$ & I & l \\
\hline & & 1 (No) & 12 & 1 & $0(+)$ & $0(+)$ & 1 & I & $0(+)$ & 1 & l \\
\hline & & & & I & $12(-)$ & $12(-)$ & I & I & $12(-)$ & l & l \\
\hline & 1 Field-grown plant & 1 (Yes) & 11 & l & $11(+)$ & $11(+)$ & I & I & $11(+)$ & 1 & I \\
\hline & (South Africa) & & & I & $0(-)$ & $0(-)$ & I & 1 & $0(-)$ & 1 & l \\
\hline \multirow{4}{*}{$\begin{array}{l}\text { "Candidatus } \\
\text { L. americanus" }\end{array}$} & 22 Field-grown plants & 20 (Yes) & 20 & I & I & I & $20(+)$ & I & i & $20(+)$ & I \\
\hline & (Brazil) & & & l & 1 & 1 & $0(-)$ & I & 1 & $0(-)$ & l \\
\hline & & $2(\mathrm{No})$ & 2 & I & I & I & $0(+)$ & I & l & $0(+)$ & l \\
\hline & & & & I & I & I & $2(-)$ & I & I & $2(-)$ & I \\
\hline \multirow[t]{2}{*}{ Total } & 204 & 126 (Yes) & 336 & $173(+)$ & $26(+)$ & $199(+)$ & $20(+)$ & $174(+)$ & $26(+)$ & $20(+)$ & $20(+)$ \\
\hline & & 78 (No) & & $103(-)$ & $12(-)$ & $115(-)$ & $2(-)$ & $102(-)$ & $12(-)$ & $2(-)$ & $60(-)$ \\
\hline
\end{tabular}

${ }^{a}$ OI1/OI2c, OA1/OI2c (13), GB1/GB3 (27), and HLBaspr, afpr, ampr (16) are 16S rDNA-based primers or probes; A2/J5 are $\beta$-operon-based primers (10). + = positive results; $-=$ negative results; / = not done.

${ }^{\mathrm{b}}$ The primers used in LAMP were $16 \mathrm{~S}$ rDNA-based rdna-F3, rdna-B3, rdna-FIP and rdna-BIP (22). 
positive, and 20 " $\mathrm{Ca}$. L. americanus"positive field-grown plants had pathogen populations in this overlapping region for these two PCR systems. These field-grown plants showed foliar blotchy mottle symptoms. However, conventional and real-time PCR assay systems did not give comparable results in tests of early detection of a "Ca. L. asiaticus" (Florida) strain in asymptomatic greenhouse-grown plants that had been experimentally inoculated (Table 2 ). The high $\mathrm{Ct}$ values (>30) of real-time PCR assays indicated a very low pathogen population in these plants during the first 2 months postinoculation. This low pathogen population was in the detection range of real-time PCR but not that of conventional PCR. The performance of the conventional and real-time PCR systems should be further evaluated with more samples from field- and greenhouse-grown plants infected by " $C a$. Liberibacter spp.", especially with asymptomatic infected plant samples which usually have a low population of the pathogens.

In summary, both the validated conventional and the newly developed real-time PCR systems are reliable for confirmatory testing for " $\mathrm{Ca}$. Liberibacter spp." in suspect HLB symptomatic citrus samples. The real-time PCR system was a more efficient tool in the early diagnosis of the disease, and it was capable of detecting " $\mathrm{Ca}$. Liberibacter spp." in asymptomatic young tissues of infected plants before detection of the pathogens was possible by the conventional PCR systems. This technique promises to be a valuable component in large-scale diagnosis and management processes as shown by current use in the ongoing U.S. HLB national survey.

\section{ACKNOWLEDGMENTS}

We give special thanks to Antonio Juliano Ayres and Diva C. Teixeira, Fundecitrus, Araraquara, São Paulo, Brazil, for providing DNA extracts from plants infected with " $\mathrm{Ca}$. L. asiaticus" and " $\mathrm{Ca}$. L. americanus". We thank Toru Iwanami, National Agricultural Research Center for the Kyushu Okinawa Region, Kumamoto, Japan, for providing DNA extracts from plants infected with " $\mathrm{Ca}$. L. asiaticus" strains from Japan and Java. We also thank S. P. van Vuuren, Institute for Tropical \& Subtropical Crops, South Africa, for providing plant materials infected with "Ca. L. africanus" strains, and Tim Schubert and Tim Gottwald for providing suspect HLB symptomatic plant materials from Florida. We thank Renee DeVries, Elizabeth N. Twieg, Kristina J. Owens, Sarika Negi, and Deric Picton of NPGBL, USDA-APHIS-PPQCPHST, Beltsville, MD, for technical assistance. We also thank Cristina Paul and Julia CabreraWoscek, USDA-ARS, for technical assistance. We thank Georgios Vidalakis, John Bash, and James Diaz from the UC Riverside Citrus Clonal Protection Program for healthy citrus materials grafted in this study. We thank Patrick J. Shiel, USDA-
APHIS-PPQ-CPHST, Raleigh, NC and L. W. Timmer, University of Florida, Lake Alfred, for comments on the paper. This research is part of project V5Q02 financed by the USDA-APHISPPQ-CPHST.

\section{LITERATURE CITED}

1. Chen, Q. 1943. A report of a study on yellow shoot of citrus in Chaoshan. New Agric. Q. Bull. 3:142-175.

2. da Graça, J. V. 1991. Citrus greening disease. Annu. Rev. Phytopathol. 29:109-135.

3. da Graça, J. V., and Korsten, L. 2004. Citrus huanglongbing: Review, present status and future strategies. Pages 229-245 in: Diseases of Fruits and Vegetables, Vol. 1. S. A. M. H. Naqvi, ed. Kluwer Academic, The Netherlands.

4. French, J. V., Kahlke, C. J., and da Graça, J. V. 2001. First record of the Asian citrus psylla, Diaphorina citri Kuwayama (Homoptera: Psyllidae), in Texas. Subtrop. Plant Sci. 53:14-15.

5. Garnier, M., and Bové, J. M. 1993. Citrus greening disease. Pages 212-219 in: Proc. Int. Organ. Citrus Virol. 12th. P. Moreno, J. V. da Graça, and L. W. Timmer, eds. IOCV, University of California, Riverside.

6. Gottwald. T. R., Aubert, B., and Zhao, X. Y. 1989. Preliminary analysis of citrus greening (Huanglungbin) epidemics in the People's Republic of China and French Reunion Island. Phytopathology 79:687-693.

7. Halbert, S. E. 1998. Entomology Section. Triology (May-June 1998) 37(3):6-7.

8. Halbert, S. E., and Manjunath, K. L. 2004. Asian citrus pysllids (Sternorrhycha: Psyllidae) and greening disease of citrus: A literature review and assessment of risk in Florida. Fla. Entomol. 87:330-353.

9. Hartung, J. S., Daniel, J. F., and Pruvost, O. P. 1993. Detection of Xanthomonas campestris pv. citri by the polymerase chain reaction method. Appl. Environ. Microbiol. 59:11431148.

10. Hocquellet, A., Toorawa, P., Bové, J. M., and Garnier, M. 1999. Detection and identification of the two Candidatus Liberobacter species associated with citrus huanglongbing by PCR amplification of ribosomal protein genes of the $\beta$ operon. Mol. Cell. Probes 13:373-379.

11. Hung, T. H., Wu, M. L., and Su, H. J. 1999. Development of a rapid method for the diagnosis of citrus greening disease using the polymerase chain reaction. J. Phytopathol. 147:599-604.

12. Jagoueix, S., Bové, J. M., and Garnier, M. 1994. The Phloem-limited bacterium of greening disease of citrus is a member of the alpha subdivision of the Proteobacteria. Int. J. Syst. Bacteriol. 44:379-386.

13. Jagoueix, S., Bové, J. M., and Garnier, M. 1996. PCR detection of the two 'Candidatus' liberobacter species associated with greening disease of citrus. Mol. Cell. Probes 10:43-50.

14. Laflèche, D., and Bové, J. M. 1970. Mycoplasmes dans les agrumes atteints de "greening", de stubborn, on des maladies similaires. Fruits 25:455-465.

15. Li, W., Brlansky, R. H., and Hartung, J. S. 2006. Amplification of DNA of Xanthomonas axonopodis pv. citri from historic citrus canker herbarium specimens. J. Microbiol. Methods 65:237-246.

16. Li, W., Hartung, J. S., and Levy, L. 2006. Quantitative real-time PCR for detection and identification of Candidatus Liberibacter species associated with citrus huanglongbing. $\mathrm{J}$. Microbiol. Methods 66:104-115.

17. Liao, X. L., Zhu, S. F., Zhao, W. J., Luo, K., Qi, Y. X., Chen, H. Y., He, K., and Zhu, X. X 2004. Cloning and sequencing of citrus huanglongbing pathogen 16S rDNA and its detection by real-time fluorescent PCR. J. Agric. Biotech. 12:80-85.

18. Lin, K. H. 1956. Observations on yellow shoot disease. Etiological studies of yellow shoot of citrus. Acta Phytopathol. Sinica 2:1-42.

19. McClean, A. P. D., and Oberholzer, P. C. J. 1965. Citrus psylla, a vector of the greening disease of sweet orange. S. Afr. J. Agric. Sci. 8:297-298.

20. Murray, M. G., and Thompson, W. F. 1980. Rapid isolation of high molecular weight plant DNA. Nucleic Acids Res. 8:4321-4325.

21. Oberholzer, P. C. J., and Hofmeyr, J. D. J. 1955. The nature and control of clonal senility in commercial varieties of citrus in South Africa. Bull. Fac. Agric. Univ. Pretoria:1-46.

22. Okuda, M., Matsumoto, M., Tanaka, Y. Subandiyah, S., and Iwanami, T. 2005. Characterization of the tufB-secE-nusG-rplKAJL$r p o \mathrm{~B}$ gene cluster of the citrus greening organism and detection by loop-mediated isothermal amplification. Plant Dis. 89:705-711.

23. Roistacher, C. N. 1991. Techniques for Biological Detection of Specific Citrus Graft Transmissible Diseases. Pages 35-45 (Greening). FAO, Rome

24. Salibe, A. A., and Cortez, R. E. 1966. Studies on the leaf mottling disease of citrus in the Philippines. FAO Plant Prot. Bull. 14:141-144.

25. Schwarz, R. E. 1968. Indexing of greening and exocortis through fluorescent marker substances. Pages 118-124 in: Proc. Conf. Int. Org. Citrus Virol., 4th. W. C. Price, ed. University of Florida Press, Gainesville.

26. Teixeira, D. C., Ayres, J., Kitajima, E. W., Danet, L., Jagoueix Eveillard, S., Saillard, C., and Bové, J. M. 2005. First report of a huanglongbing-like disease of citrus in São Paulo State, Brazil and association of a new Liberibacter species, "Candidatus Liberibacter americanus", with the disease. Plant Dis. 89:107.

27. Teixeira, D. C., Danet, J. L., Eveillard, S., Martins, E. C., Jesus, W. C., Jr., Yamamoto, P. T., Lopes, S. A., Bassanezi, E. B., Ayres, A. J., Saillard, C., and Bové, J. M. 2005. Citrus huanglongbing in São Paulo, Brazil: PCR detection of the 'Candidatus' Liberibacter species associated with the disease. Mol. Cell. Probes 19:173-179.

28. Teixeira, D. C., Saillard, C., Eveilard, S. Danet, J. L., Ayres, A. J., and Bové, J. M. 2005. Candidatus Liberibacter americanus sp. nov., associated with citrus huanglongbing (greening disease) in São Paulo, Brazil. Int. J. Syst. Bacteriol. 55:1857-1862.

29. Tian, Y., Ke, S., and Ke, C. 1996. Polymerase chain reaction for detection and quantification of Liberobacter asiaticum, the bacterium associated with huanglongbing (greening) of citrus in China. Pages 252-257 in: Proc. Conf. Int. Org. Citrus Virol., 13th. J. V. da Graça, P. Moreno, and R. K. Yokomi, eds. IOCV, University of California, Riverside.

30. Wu, S. P. 1987. Direct fluorescence detection for diagnosing citrus yellow shoot disease. Proc. Workshop Citrus Greening Disease, Fuzhou, China. p. 3. 